\title{
Geology and composition of the Nakyn field kimberlite pipes and diamond properties (Yakutia)
}

\author{
S.D.Cherny ${ }^{1}$, A.S.Fomin ${ }^{1}$, Ju.T.Yanygin ${ }^{1}$, V.I.Banzeruk ${ }^{1}$, V.P.Kornilova ${ }^{2}$
}

1. Botuobonskaya Prospect-and-Exploration Expedition, ALROSA Joint-Stock Company,Russia

2. Yakutian Institute of Geological Sciences, Siberian Branch, Russian Academy of Sciences.

The Botuobinskaya and Nurbinskaya kimberlite pipes recently discovered whithin the Nakyn kimberlite field at the centre of the Vilyui-Markha tectonic zone by geologists of the Botuobinskaya expedition were dated at the Middle Paleozoic based on geological evidence (sedimentary rock xenoliths with fauna $\mathrm{S} 1$ ) and $\mathrm{Rb} / \mathrm{sr}$ age determinations. The country rocks are terrigeneouscarbonate rocks of Early Paleozoic age. The pipes are overlain by terrigeneous rocks of Early Jurassic age.

The two pipes are close in the rock composition and diamond content. They are thought to be unique, transcending, in many ways, all previously discovered deposits within the Yakutian diamondiferous province. The pipes are highly productive and the diamonds extracted from them are of outstanding quality. The rocks of the pipes are characterized by peculiar petrographic, mineralogical and petrochemical composition. The indicator minerals are specific too. The emplacement of the pipes occurred in two phases: subvolcanic and volcanic. The former is represented by north-east trending dykes of porphyritic kimberlite (PK), the latter - by autolithic kimberlite breccias (AKB) and kimberlite tuff breccias (KTB of Botuobinskya pipe), making up the diatreme and crater zones of the kimberlite bodies, respectively. The Botuobinskaya pipe has all the three zones typical of a kimberlite body, i.e. a dyke, a diatreme and a crater. The Nyurbinskaya pipe was eroded at the diatreme level and is almost entirely comprised of AKBs. PKs occur only as thin dykes in the southwest part of the pipe and as numerous small fragments (up to $10 \mathrm{~cm}$ ) and rare large blocks $(10-15 \mathrm{~m})$ in the northeast flank.

A typomorphic feature of PKs in both pipes is an extremely high content (up to 5\%) of metamorphic rock xenoliths: gneiss, schist and lesser granulite. PKs have a coarsely porphyritic texture. Olivine occurs in two generations: mantle-derived xenocrysts and euhedral olivine, both entirely replaced by secondary minerals such as serpentine, chlorite and calcite. The latter dominates in the endocontact zones. At deep levels (greater than $140 \mathrm{~m}$ ) the groundmass is dominated by serpentine (40-45\%) and fine calcite (15-20\%). The amounts of finely-dispersed ore impregnation and perovskite are extremely low: $0,4 \%$ and $0,2 \%$, respectively. At the upper levels, the phlogopite is entirely replaced by chlorite.

AKBs of both pipes have a distinct autolithic structure. An autolith has a core and a zonal rim with tiny (less then $0,1 \mathrm{~mm}$ ) constituents of kimberlites (minerals, xenoliths) arranged in orbits. A typomorphic feature of AKBs in the Nyurbinskaya pipe is a high percentage of metamorphic rock xenoliths (up to $8 \%$ ) similar to those from PKs. AKBs of the Botuobinskaya pipe are dominated by sidementary rock xenoliths. Olivines of two generations are entirely replaced by serpentine, chlorite and calcite. The latter prevails in the upper zones of the pipes. The amount of pseudomorphs after olivine of the first generation is extremely high (up to 23-25\%), the highest among the recognized varieties of kimberlite.

In the upper zones of the pipes, the cementing medium of AKBs is fine-grained with prevailing calcite, chlorite and clay minerals. At lower levels, the content of serpentine increases and lath-like 
phlogopite appears. The amounts of ore minerals and perovskite are extremaly low (less than in the PKs).

KTBs fill in the crater of the Botuobinskaya pipe. The crater has a shape of a rootless trough-like body about $200 \mathrm{~m}$ thick. The source rocks of KTBs are AKBs enriched in clastic material (70-80\%) derived from the host rocks. The hybrid cement of KTBs contains a significant admixture of carbonaceous, clay and terrigeneous material due to desintegration of sedimentary rock xenoliths. The kimberlite minerial is represented by rare autiloths and their relics as well as by pseudomorphs after olivine of both generations and their fragments.

All the recognized varieties of kimberlite rocks from the two pipes are characterized by anomalously low weight contents of the whole of heavy fraction $(1.92 \mathrm{~kg} / \mathrm{t}$ to $6.82 \mathrm{~kg} / \mathrm{t})$ and of indicator minerals: pyrope $(0.27 \mathrm{~kg} / \mathrm{t}$ in $\mathrm{KTBs}$ to $0.45 \mathrm{~kg} / \mathrm{t}$ in $\mathrm{AKB})$ and chrome-spinellide $(0.06$ $\mathrm{kg} / \mathrm{t}$ in $\mathrm{AKB}$ to $0.16 \mathrm{~kg} / \mathrm{t}$ in PKs). Picroilmenite is absent. Ore minerals are low in content $(0.05 \mathrm{~kg} / \mathrm{t}$ to $0.59 \mathrm{~kg} / \mathrm{t})$. Zircon and rutile released from the crystalline basement xenoliths amount to $0.05 \mathrm{~kg} / \mathrm{t}$ and $0.07 \mathrm{~kg} / \mathrm{t}$, respectively.

Microprobe analysis revealed a relatively low content of pyrops of the diamond assosiation in all the above mentioned kimberlite varieties, ranging from $4.0 \%$ in $\mathrm{PKs}$ and $\mathrm{AKBs}$ of the Nyurbinskaya pipe to $8 \%$ in AKBs of the Botuobinskaya pipe. The pyrope belonging to the lherzolite paragenesis prevails. From optical-spectroscopic studies, the content of orange-red pyrops from diamondiferrous magnesian-ferruginous eclogites is estimated at $14 \%$. On the diagram of $\mathrm{CaO}-\mathrm{Cr}_{2} \mathrm{O}_{3}$, composition points of these rocks fall into the feld of the lherzolite paragenesis. The amount of chrome-spinellide of the diamond association is very high (up to $25-30 \%$ ).

In terms of chemical composition, all the recognized varieties refer to high- $\mathrm{K}$ (average $\mathrm{K}_{2} \mathrm{O}$ from 0.88 to 1.71 wt.\%), low $\mathrm{TiO}_{2}\left(\mathrm{TiO}_{2}\right.$ from 0.33 to 0.73 wt. \%), low $-\mathrm{Fe}\left(\mathrm{Fe}_{2} \mathrm{O}_{3}\right.$ from 4.60 to 7.19 wt.\%) kimberlite rocks. $\mathrm{PKs}$ are higher in $\mathrm{SiO}_{2}, \mathrm{TiO}_{2}, \mathrm{Fe}_{2} \mathrm{O}_{3}, \mathrm{MgO}$ and $\mathrm{P}_{2} \mathrm{O}_{5}$ and lower in $\mathrm{CaO}$ and $\mathrm{K}_{2} \mathrm{O}$ relative to the other kimberlite varieties. Regularity in the distribution of oxides in the recognized varieties is, in general, similar to that characteristic of well-known kimberlite pipes within the Yakutian diamondiferous province.

The Botuobinskaya and Nyurbinskaya pipes are distinguished by pecuilar typomorphic features of diamonds. In accordance with morphological classification of Ju.L. Orlov (1973), any diamond sample from both pipes contains $94-96 \%$ Group I diamonds. Diamonds of Group II do not exceed $0,5 \%$ and those of Group VIII are no more than $1 \%$. More common (4-5\%) are diamond crystals of Group IV ("coated diamonds") with a yellow green coating and characteristic faces. A typical feature of Group I diamonds is the presence of significant amounts of crystals of pseudocubic habit and pseudorhombododecahedra (combinative polyhedra of the octahedron-rhombododecahedron cube series), but the most common are diamonds of the transition habit and laminar rhombododecahedra. Group II diamonds are represented by milk-white and grey cuboids. A high proportion of diamond crystals from both pipes show pink-lilac and blue photoluminescence in UVlight. Solid inclusions in diamonds are represented by syngenetic and epigenetic minerals. The former include chromite, olivine and crimson pyrop. Most common among the epigenetic minerals are graphite and sulfide and their combinations. Insignificant amounts of diamonds with green pigment are also present.

In terms of composition and initial Sr87/Sr86 ratio, the rocks of both pipes belong to Group 2 kimberlites. It is for the first time that kimberlites of this group have been reported from the Yakutian diamondiferous province. 